\title{
The Politics of Environmental Activism: a Case Study of the Cruise Industry and the Environmental Movement
}

\author{
by Ross A. Klein \\ Memorial University of Newfoundland \\ Sociological Research Online, Volume 12, Issue 2, \\ < http://www.socresonline.org.uk/12/2/klein.htm/> \\ doi:10.5153/sro. 1548
}

Received: 6 Oct 2005 Accepted: 26 Mar 2007 Published: 30 Mar 2007

\begin{abstract}
Based on a case study of environmental organizations' confrontation of the cruise industry over environmental practices, this article critically assesses several campaigns and actions by the environmental movement as represented by several key organizations that focus specifically on the cruise industry, and at the social and political processes used by the cruise industry to deal with these organizations. Five environmental groups are included in the case study; the cruise industry is represented by the three major cruise corporations (comprising more than $90 \%$ of the North American and European market), their marketing agents and lobbyists. Strategies used by environmental organizations and by the cruise industry are identified and analysis seeks to explain factors associated with the effectiveness or noneffectiveness of these strategies.
\end{abstract}

\section{Keywords: Community Action, Environment, Social Movements, Political Sociology, Social Change, Social Capital, Cruise Industry, Cruise Ship, Social Activism}

\section{Introduction}

1.1 The cruise ship industry is the fastest growing segment of the leisure travel market. The number of North Americans taking a cruise rose from less than 600,000 persons to over 10 million between 1970 and 2005 (see Cruise Lines International Association, 2005). Growth in the UK and Europe historically has been much less robust, but growth figures in recent years have outpaced the percentage growth for the same years in North America. Between 2003 and 2005 Southampton's passenger numbers increased from 480,000 to 700,000 ; Aberdeen, Invergordon, and Liverpool each doubled its passenger numbers and with a new $£ 19$ million cruise terminal Liverpool's numbers will undoubtedly continue to soar. In 2005 , an estimated 1.25 Britons will take a cruise (see Cruise Europe News, 2005). Recent growth follows expansion associated with takeover by US-based Carnival Corporation of traditional British brands such as Cunard, P\&O, Princess, and Swan Hellenic. Carnival has also taken control of the largest cruise lines in Italy and Germany and has positioned itself as the dominant player across Europe.

1.2 With growth and the increased presence of cruise ships, Europe will face problems already faced in North America; particularly issues around the cruise industry's impact on coastal and marine environments. This article focuses on the emergence of environmental activism toward the cruise industry in North America and provides insight and lessons for those in Europe, Asia, Australia, and South America who are likely to be confronted with the same problems. To date, environmental activism toward the cruise industry outside North America has been limited, often depending on a single individual or a small, isolated group. In most cases it has been in response to government plans to build new cruise reception facilities and docks, as was the case in late-2005/early-2006 on Australia's Gold Coast where a group calling itself 'Save Our Spit' confronted the local and state government. In most locales, the cruise industry has effectively compromised nascent opposition.

1.3 As a case study, this article is rich in detail about the relationship between the cruise industry and environmental activists. It is less rich with regard to theory and theory building. While much could be drawn from the literature on social movements, political sociology, and social change, the focus here is not on building theory or on demonstrating the 'goodness of fit' of theory. Few sociologists have studied or written about the cruise industry, which is a recent and unique phenomenon. None have engaged in the sort of field 
research and archival research yielding the cases discussed here. The greater need now, for theoretical and applied sociologists, is to gain an understanding of the uniqueness of the cruise industry phenomenon - a global industry that conveniently uses its deployment of foreign-flagged vessels by foreign-registered corporations to its continual advantage. This understanding will lead in due time to elucidating current theory and theory development.

\section{The problem}

2.1 The cruise ship industry devotes considerable resources to project an image of environmental responsibility. Royal Caribbean International $(\mathrm{RCl})$ has had its 'Save the Waves' campaign for more than a decade, in the mid-1990s created its Ocean Fund, and more recently created its internally-awarded 'environmental ship of the year' award. Others have followed suit. Holland America Line has 'Seagoing Environment Awareness (SEA),' Princess Cruises has 'Planet Princess,' and Crystal Cruises has 'Crystal Clean.' Efforts by individual cruise lines are augmented by the International Council of Cruise Lines (ICCL), the industry's main lobbying and political advocacy group, which following major environmental violations issued environmental statements and commitments in 1999, 2001, and 2003. The European Cruise Council, established in April 2004 and headed by Carnival Corporation executive and CEO of Costa Cruises, Pier Luigi Foschi, is positioned to play the same role in Europe as the ICCL in the US.

2.2 The cruise industry's apparently sincere efforts to project a 'green' image has a backdrop of habitual environmental violations. In October 1992, the U.S. Government complained to the International Maritime Organization's Marine Environmental Committee meeting that it had reported environmental violations to the appropriate flag states 111 times, but received responses in about 10 percent of the cases. Few of these were ever pursued.

2.3 The US responded with stricter enforcement. Between 1993 and 1998 it charged 104 ships with offences involving illegal discharges of oil, garbage, and/or hazardous wastes (GAO, 2000). But this is the tip of the iceberg. The cruise industry's largest players are foreign registered corporations (e.g., Panama, Liberia, Bermuda, Bahamas) operating foreign-registered ships; as such, countries and ports they visit have limited ability to apply and enforce national and international regulations. Regardless, between 1993 and 1998 the US Coast Guard reports it charged cruise ships with 490 safety or environmental violations, and an additional 73 tickets were issued for oil spills of 378 litres or less (Herz and Davis, 2002:40).

2.4 Princess Cruises was among the first to be caught. In 1993, passengers videotaped crew members throwing 20 plastic bags of garbage overboard off the Florida Keys. Princess paid a $\$ 500,000$ fine (Glass, 1993). A year later, Palm Beach Cruises was fined $\$ 1$ million after Coast Guard surveillance aircraft videotaped the Viking Princess' intentional dumping of waste oil, leaving a 2.5 mile slick 3.5 miles from the port of Palm Beach. Also in 1994 began the case that brought cruise ship dumping to the front page of newspapers across North America. Surveillance aircraft observed Royal Caribbean's Sovereign of the Seas illegally discharging oily bilge and an investigation began. Between 1998 and 2000, Royal Caribbean was fined $\$ 30.5$ million for violations spanning the 1990s that include discharge of oily bilge, dry cleaning fluids, photographic chemicals, solvents from the print shop, and falsifying records to conceal their practices (Klein, 2002:88-89). Holland America Line paid \$2 million in fines and restitution, also in 1998, following a 1995 incident in which it pumped overboard oily bilge water in Alaska's Inside Passage. The violation was reported by the ship's assistant engineer (Juneau Empire, 1998).

2.5 In 2002, Carnival Corporation (Holland America Line's parent company) pleaded guilty to six counts of falsifying records in relation to oil discharges between 1998 and 2001 from five ships operated by Carnival Cruise Line and paid \$18 million in fines and restitution (McDowell, 2002); and Norwegian Cruise Line (NCL) pleaded guilty to discharge of oily bilge and falsifying its discharge logs between 1997 and 2000; it paid $\$ 1.5$ million in fines and restitution. Agents with the US Environmental Protection Agency say that Norwegian Cruise Line's (NCL) Norway '....also dumped raw sewage mixed with hazardous, even cancer causing, chemicals from dry cleaning and photo development into the waters near Miami for many years' (Adams, 2002).

2.6 It doesn't stop there. Carnival Corporation was summoned to federal court in July 2003 after a probation officer reported that the company failed to 'develop, implement and enforce' the terms of an environmental compliance program stemming from its 2002 plea agreement; Holland America employees reportedly submitted 12 audits that contained false, misleading and inaccurate information (Dupont, 2003). Carnival Corporation replied to the court that three environmental compliance employees had been fired for the reports, but the company did not admit violating its probation. In a settlement signed 25 August, 2003 Carnival agreed to hire four additional auditors and to provide additional training for staff (Perez, 2003). The company was again under investigation in March 2004 for illegal discharges from a Holland America ship and in July 2004 a former vice president for environmental compliance plead guilty to certifying environmental compliance audits that had never been done (Klein, 2005). There have been a series of other 
violations, including discharges of raw sewage in Juneau Harbour, in Puget Sound, and in the Monterey Bay Marine Sanctuary. Table 1 provides a summary of known offences between 2001 and 2003.

TABLE 1: Summary of Environment 'Events,' 2001 - 2003

\begin{tabular}{|c|c|}
\hline Date & Event \\
\hline 2001 & $\begin{array}{l}\text { January to May - Carnival's Holiday discharges } 768,000 \text { gallons of grey water (nearly } 40,000 \text { gallons per week for } 20 \\
\text { weeks) into the port of San Pedro, California } \\
\text { May - Norwegian Sky discharged treated sewage in the Alexander Archipelago. Fecal coliform } 3500 \text { times the abwadle } \\
\text { federal standard and suspended solids } 180 \text { times the standard. } \\
\text { May - Holland America's Westerdam accidentally discharged grey wastewater while docked in Juneau. Apasserby who } \\
\text { noticed an odd color and odour in the water reported the incident to the Coast Guard. It was estimated that } 100 \text { gallons } \\
\text { of gray water was discharged when a valve failed to close completely. } \\
\text { June - Crystal Cruise's Mercury discharged treated wastewater in Juneau. Although the ship had cutting-edge } \\
\text { technology for treatrnent of wastewater, it hadn't yet received approval to discharge in protected areas. Tests of the } \\
\text { wastewater indicated that it was more acidic than permitted for discharging within a mile from shore. } \\
\text { June - Royal Caribbean's Rhapsody of the Seas discharged } 200 \text { gallons of grey water into Juneau's harbour when } \\
\text { wastewater was being transferred to a holding tank. The holding tank had exceeded its capacity andthewastewater was } \\
\text { discharged through an overboard discharge valve. } \\
\text { Summer - } 11 \text { ships (6 companies) cited for violation of Alaska's air opacity standards. } \$ 247,500 \text { in fines. } \\
\text { October -- Spirit of Oceamus Discharged } 24,000 \text { gallons of grey water in the port of San Diego } \\
\text { December - Court-required audit cited Celebrity Cruises' Zenith of offloading at Tarnpa as non-hazardous waste a } 55 \\
\text { gallon drum of hazardous waste was offloaded. }\end{array}$ \\
\hline 2002 & $\begin{array}{l}\text { February - P\&O's Caronia detained and fined by Brazilian authorities after nearly } 8000 \text { gallons of heavy fuel oil spilled } \\
\text { into Guanabara Bay near Rio de Janeiro. Departure delayed one day and ship fined } \$ 410,000 \text {. } \\
\text { August - Holland America Line's Ryndam discharges approximately } 40,000 \text { gallons ( } 250 \text { gallons according to HAL) of } \\
\text { sewage sludge into Juneau harbour. Plea bargain announced January } 2005 \text {; fine and restitution: } \$ 2 \text { million. } \\
\text { Summer - } 1 \text { ship cited for violation of Alaska's air opacity standards. } \\
\text { October - Crystal Harmonyreported in March } 2003 \text { that contrary to a written promise to not discharge in the Monterey } \\
\text { Bay Marine Sanctuary, the ship had in fact discharged } 36,000 \text { gallons of treated bilge, treated sewage, and grey water. } \\
\text { October to December - Royal Caribbean International admits to } 7 \text { violations of the industry's Memorandum of } \\
\text { Understanding with the State of Hawaii }\end{array}$ \\
\hline 2003 & $\begin{array}{l}\text { January to October - Royal Caribbean International, Princess Cruises, and Holland America Line each admit to } \\
\text { multiple violations of the industry's Memorandum of Understanding with the State of Hawail } \\
\text { January - Carnival Cruise Lines' Ecstasy discharged } 60 \text { gallons of grey water while anchored at Avalon Bay (Catalina } \\
\text { Island, California), approximately one-half mile from land. } \\
\text { February-A couple aboard the Nonwegian Wind reported observing whole beer bottles, whole wine bottles, beer and } \\
\text { pop cans, corks, plastic plates, plastic utensils, plastic cups and organic material all being tossed into the ocean fromthe } \\
\text { back of the ship. The ship was between Hawaii and Fanning Island. The company insists it did nothing illegal. Discharge } \\
\text { of plastics is strictly forbidden anywhere at sea. } \\
\text { May - Nonwegian Sun is cited for the illegal discharge of } 16,000 \text { gallons of raw sewage into the Strait of Juan de Fuca } \\
\text { (just off Whidby Island, a popular vacation resort). } \\
\text { Summer - } 1 \text { ship cited for violation of Alaska's air opacity standards. } \\
\text { August -- At the new cruise ship terminal at the Port of Seattle, cruise ships fail to abide by requirement to use low- } \\
\text { sulphur diesel fuel while docked - a violation of the state environmental mandates for the project. } \\
\text { October -- Carnival Cruise Line paid } \$ 200,000 \text { administrative fee to settle with the California State Lands Commission } \\
\text { over the cruise line's non-cornpliance with state ballast water law. }\end{array}$ \\
\hline
\end{tabular}

Adapted from Ross A. Klein. (2003) The Cruise industry and Environmental History and Practice: is a Memorandum of Understanding Effective for Protecting the Environment? San Francisco: Bluewater Network.

shttp:IWww.bluewaternetwork.orgireportsirep_ss_kleinrep.pdf = 


\section{Environmental organizations respond}

3.1 The environmental community's response to the practices and offences of the cruise industry was slow in developing. Many groups well known for their environmental stances have been silent about the cruise industry, among them Greenpeace and the World Wildlife Fund (WWF). Before addressing reasons for silence, it would be useful to identify those organizations that have entered the fray. The focus is on organizations that go beyond a local and therefore limited base.

3.2 Bluewater Network, based in San Francisco, is on the forefront of environmental activism related to the cruise industry. The organization began in 1996 as a project within Earth Island Institute. In six years, it grew into a national organization with membership in four countries and had led the successful effort to ban two-stroke marine engines, rid almost all US National Parks from snowmobiles and jet skis, convinced the US Environmental Protection Agency (EPA) to regulate air pollution from ships, helped ban MTBE (a gasoline additive) in California, and led the environmental community in a historic fight to reduce global warming pollution from cars and light trucks. In 2002, Bluewater Network became an independent, non profit organization and in 2005 merged with Friends of the Earth.

3.3 Bluewater Network uses a mix of strategies. In regard to the cruise industry, it has used the courts to pressure the EPA to promulgate regulations to control vessel emissions, to force cruise lines to stop their habitual violation of laws prohibiting the discharge of ballast water in California waters, and in 2003/2004 to challenge EPA standards for air emissions from ships. Bluewater Network also engages in political lobbying - it was successful in 2003 in having enacted two of three bills it sponsored in the California legislature; it sponsored three bills that were enacted in 2004. And it was involved in ensuring sufficient environmental protections around construction of a new cruise terminal in San Francisco. Through legislation, Bluewater Network has prohibited cruise ships from discharging grey water from kitchens; from dumping sewage (treated or untreated) into state waters; from burning garbage, paper, sludge, and any other materials in onboard incinerators while operating within three miles of the California coast; and from discharge of hazardous waste into state waters (see Klein, 2005:168-169).

3.4 Bluewater Network supports efforts of organizations in other jurisdictions. It participated in a lawsuit in Washington State following discharge of raw sewage in Puget Sound by Norwegian Cruise Line, brought to light cruise line violations of emission standards set by the Port of Seattle, and has engaged in public education and social action campaigns in San Francisco, Seattle, and beyond. In 2006, Bluewater Network/Friends of the Earth leant its support to 'Save Our Spit's' efforts to protect Australia's Gold Coast, a campaign that achieved success in August 2006 with the Queensland Government's cancellation of plans for a cruise terminal near Surfer's Paradise.

3.5 Campaign to Safeguard America's Waters (C-SAW) also began as a project of Earth Island Institute. It is dedicated to closing loopholes in federal and state water pollution regulations that allow millions of gallons of polluted wastes to be dumped into public waters, and is actively engaged in the debate about the use of mixing zones to circumvent water quality standards. The cruise industry advocates mixing zones, in effect saying 'dilution is the solution' to discharge of its wastes.

3.6 C-SAW's efforts around water quality standards and the EPA are national in scope, however the campaign is also intimately involved in Alaska's efforts to contain and control pollution produced by cruise ships. The organization's founding is related to discharge of hazardous chemicals (dry cleaning fluids, photofinishing chemicals, and more) in Alaska's Inside Passage, including waters around Haines on which the Campaign's founder had depended for salmon. C-SAW has also been a key player in a ballot initiative designed to tax cruise ships using Alaska's waters (Cockerham, 2004). The cruise industry unsuccessfully challenged the ballot initiative through appeals to the Governor and the courts (Klein, 2005: 115). A vote, scheduled in the summer 2006, endorsed the initiative which included a $\$ 50$ per passenger tax, provisions for deployment of 'Ocean Rangers' on all ships sailing to/from Alaska, and corporate disclosure of some economic relationships.

3.7 Oceans Blue Foundation (OBF) was established in 1996 through a cooperative effort involving the Vancouver Port Authority, Tourism Vancouver, Tourism British Columbia, the Canadian Tourism Commission, private foundations, and business leaders in British Columbia. Once established, OBF operated independently from its government and quasi-government founders. Its 'Cruise Ship Stewardship Initiative' was a key project. The Initiative focussed on the cruise industry voluntarily adopting standards of environmentally responsible tourism. OBF's goal was an eco-certification program that would identify and reward cruise lines that took meaningful and positive steps. The initiative began with a series of meetings between the cruise industry (including the NorthWest Cruiseship Association (NWCA) which like OBF was located in Vancouver) and OBF. These meetings culminated in a March 2002 roundtable involving representatives of the cruise industry and environmental organizations. A critical turning point was reached before the roundtable occurred. 
3.8 In preparation for the roundtable, OBF convened environmental groups and organizations for a discussion of strategy and cooperation. One of the invited groups was Vancouver-based David Suzuki Foundation. The foundation's president came to the meeting with a member of the organization's board of directors. Given the sensitivity of the meeting, her guest was asked whether he had ever been employed by the cruise industry or held a contract with the cruise industry. He volunteered that his firm was the public relations firm for the NWCA as well as for the David Suzuki Foundation. Though he said he had much to offer to the meeting, he was told that only environmental nongovernmental organizations (ENGOs) were invited and he would have to leave.

3.9 The relationship between OBF and the cruise industry changed shortly thereafter. OBF, previously viewed as a potential partner, was now perceived with caution and suspicion. The NWCA's public relations firm reportedly undertook a risk assessment of all of the ENGOs participating in the meeting and subsequently convened an industry strategy session prior to the joint roundtable.

3.10 The roundtable's potential was limited by mutual distrust and did not live up to either side's expectations. The positive working relationship of past had become strained and was further deteriorating. There was posturing, cloaked threats, and other forms of political gamesmanship. With the potential slipping away for industry cooperation on a plan for eco-certification and commitment to greater environmental responsibility, OBF became more confrontational. This culminated in Blowing the Whistle and the Case for Cruise Ship Certification, an October 2002 report directly confronting contradictions between industry claims and practices.

3.11 OBF lost most of its funding in retribution. Tourism Vancouver criticized the report and said ' $[\mathrm{t}$ ] here are better ways of being able to encourage that kind of discussion and debate,' that the matter would be raised with the Canadian Tourism Commission (CTC), and that Tourism Vancouver would consider ending support for OBF. An official with the CTC was also critical, suggesting that 'the CTC supports a balanced approach between environmental protection and economic development' (Tjaden, 2002). OBF closed its doors a year later. A follow up to the October 2002 report, completed in September 2003, was never released.

3.12 The Ocean Conservancy (TOC), formerly known as the Centre for Marine Conservation, became directly involved in cruise industry issues with release in May 2002 of Cruise Control: A Report on How Cruise Ships Affect the Marine Environment. Two years earlier Royal Caribbean's (RCl) Ocean Fund provided a grant of $\$ 450,000$ ( $\$ 150,000$ per year for three years) to TOC. TOC gave RCl advance notice of the report, and the report's release was reportedly delayed because of the cruise line's objections. $\mathrm{RCI}$ immediately criticized the report when it was released, and gave notice of its intent to withdraw funding from The Ocean Conservancy's projects.

3.13 The Ocean Conservancy engages in both national and local activities. Through its field offices in Monterey Bay (California) and Key West (Florida), TOC has been a key player in local initiatives to contain and prevent cruise ship pollution in adjacent National Marine Sanctuaries. In Monterey Bay specifically, TOC was a critical force in coordinating efforts of a range of organizations toward providing public education and in applying pressure on local government. It was among three sponsors of a public event concerned with cruise ship pollution at the Monterey Institute for International Studies in January 2002. Contrary to claims by the Vice Present of Crystal Cruises (who attended on behalf of the International Council of Cruise Lines) of the industry's exemplary environmental concern, local citizens learned three weeks later that Crystal Cruises' ship had violated a written promise to not discharge any effluent in the Monterey Bay Marine Sanctuary - the company excused its behaviour by saying it hadn't broken any laws, it had only broken its word. Local backlash led to Crystal being banned from Monterey for 15 years; the offending ship was banned in perpetuity (see Fletcher, 2003; Laidman, 2003; Madigan, 2003). On a national level, TOC (along with Bluewater Network) was a key proponent for the Clean Cruise Ship Act of 2004, however resources devoted to cruise ship issues are relatively small in comparison to other activities. The Clean Cruise Ship Act, introduced in the US Congress April 2004, died in committee. It was reintroduced in 2005 and languished in committee with little action through the end of the 2005-2006 Congressional Session. With a shift to a Democratic Party-controlled Congress, the Act will likely fare better when reintroduced in late-Spring or early-summer 2007.

3.14 Oceana is the newest player on the scene. Established in 2001 with funding largely from the Pew Charitable Trusts, Oceana merged with the American Oceans Campaign in 2002. It identified cruise ship pollution as one of its key areas of interest and undertook a cruise ship campaign in early 2003. Similar to OBF, Oceana began by collaborating with the cruise industry - in its case engaging in discussions with Royal Caribbean Cruises Limited (operator of Royal Caribbean International and Celebrity Cruises) and calling for a commitment to upgrade wastewater treatment systems. Oceana at the same time engaged in public education and mild forms of social and political action. 
3.15 Discussions between Oceana and Royal Caribbean broke down in July 2003. In Oceana's words, they had been negotiating with Royal Caribbean, whereas Royal Caribbean said it had engaged in meetings as part of its routine outreach to interest groups, environmental organizations, academic institutions, and others (Londner, 2003). Oceana responded with a media campaign beginning 21 July, 2003, and held rallies and media events in several cities across North America. The CEO of Royal Caribbean issued a form letter on 24 September, 2003 responding to letters he received as part of Oceana's campaign. He clearly stated that the company discharged its black water (wastes from toilets) and its grey water (wastewater from sinks and the galley) 'only when we are 12 or more miles from the shore and moving at least 6 knots.' The letter proudly promoted Royal Caribbean's policies and procedures for exceeding Coast Guard requirements and as stricter than US law. In December 2003, these claims were thrown into question when the State of Hawaii reported that the company had 12 times violated a memorandum of understanding which prohibits discharges within four miles of the coast (Yamanouchi, 2003).

3.16 Oceana escalated its campaign in October 2003, calling for a national boycott of Royal Caribbean, and in February 2004 placed advertisements for its cruise ship campaign on Google.Com. After two days the ads, which did not mention Royal Caribbean by name, were banned. Google claimed that the ads violated its editorial policy which prohibits ads criticizing other groups or companies. The ads reappeared two weeks later on Yahoo. In May 2004 Royal Caribbean announced a commitment to install advanced wastewater treatment systems on all of its ships by 2008 - exactly what Oceana was calling for. But RCCL also said that Oceana's campaign had nothing to do with its decision. Coincidentally, the Clean Cruise Ship Act introduced in April 2004 required advanced wastewater treatment systems on all cruise ships discharging in US territorial waters (between 12 and 200 miles).

3.17 Oceana partners with Bluewater Network and The Ocean Conservancy (TOC) in advocating for the Clean Cruise Ship Act. These efforts can be distinguished from those of Bluewater Network more generally and OBF in that the latter are more comprehensive. TOC's and Oceana's efforts focus largely on wastewater and bilge water. Bluewater Network and OBF include in their campaign ballast water, air emissions, and toxic waste. None of the groups has focussed directly on the 3.5 kilograms of solid waste produced per passenger per day on a cruise ship - 7 metric tons of garbage and solid waste per day on today's largest ships.

\section{The cruise industry defends itself}

4.1 Aside from cruise lines' early attempts to colour themselves green with slogans, Royal Caribbean was the first to initiate projects that could be construed as environmentally responsible. While it was under investigation for violations in 1994, but before its plea bargains in 1998, the cruise line introduced its Ocean Fund. The Ocean Fund was established in 1996 to support marine conservation organizations in their efforts to preserve the ecosystems of the world's oceans - a goal that was ironic in light of the company's environmental practices. The Ocean Fund's mission is to support efforts to restore and maintain a healthy marine environment, minimize the impact of human activity on this environment, and promote awareness of ocean and coastal issues and respect for marine life.

4.2 Between 1996 and 2004, the Ocean Fund awarded over $\$ 4.6$ million to 41 separate organizations. Sixteen organizations received $\$ 100,000$ or more and collectively account for 77 percent of all money granted. The largest recipients were TOC and the US World Wildlife Fund ( $\$ 700,000$ each), National Audubon Society and The Ocean Conservancy ( $\$ 500,000$ each) and the National Marine Sanctuary Foundation $(\$ 200,000)$. There have also been contributions to universities and to other programs; generally organizations that have concern with the environment but whose work does not directly impact the cruise industry or issues related to cruise ships.

4.3 The Ocean Fund has been strategic. Aside from culling support from national organizations, it has given money to local organizations where the industry is expanding or where it wants to raise its image. In 2004 it awarded a $\$ 200,000$ grant to the National Marine Sanctuary Foundation for the Nancy Foster Florida Keys Eco-Discovery Centre in Key West, Florida. A key consideration in making the donation was that a plaque acknowledging Royal Caribbean's support would be placed in the visitor centre entrance (O'Hara, 2004). The centre will be included in shore excursions offered by cruise ships stopping at Key West, a city that had become increasingly hostile toward cruise tourism. The grant to the World Wildlife Fund (WWF) is also interesting. Perhaps coincidentally, the Board Chair of WWF is a member of the Board of Directors of Royal Caribbean; he's also an environmental consultant to the company with an annual fee of $\$ 300,000$, which is on top of his stipend as a member of the Board of Directors.

4.4 Conservation International $(\mathrm{Cl})$, an organization that sounds like it would be environmentally responsible but whose behaviour suggests other motives, also receives money from The Ocean Fund: \$60,000 in 2004. This comes on the heels of an announcement in late 2003 that the International Council of Cruise Lines (ICCL), the cruise industry's Washington-based lobbyist representing 15 companies with a 90 percent share 
of the North America cruise line business, had entered a partnership with Conservation International. Together they created the Ocean Conservation and Tourism Alliance, a project toward which ICCL will contribute $\$ 850,000$. While on surface the initiative appears to be environmentally 'green,' the fact that Conservation International has recently come under attack for representing corporate interests over environmental concerns cannot be ignored (Ruiz-Marrero, 2003; Choudry, 2003).

4.5 The ICCL - Cl partnership was formally announced in December 2003, but began much earlier. Cl presented a report (see Sweeting and Wayne, 2003) from its 2002-initiated Cruise Industry Initiative at the World Cruise Tourism Summit in Miami Beach in March 2003. The presentation, made at the request of the ICCL, complimented the cruise industry for responding to environmental challenges, encouraged it to continue to use leading practices, and recommended establishing a formal partnership with Conservation International. There was no cognizance of recent environmental violations and ongoing litigation.

4.6 Another key strategy used by the cruise industry involves protecting itself from environmental regulation. It actively lobbied against three pieces of legislation in California in 2003 - effectively killing a measure that would have forced use of cleaner burning fuels while in state waters and gutted provisions to protect against discharge of grey water and sewage (Weiss, 2003). The industry similarly blocked legislation in Washington State (Lange, 2004) and actively worked against legislation in Maine. Their success results from a combination of lobbying and campaign contributions. In the State of Alaska alone, between 1998 and 2004, the cruise industry contributed $\$ 585,000$ to campaigns for state political offices; another $\$ 250,000$ on campaigns of the state's three members of Congress, and in recent years has spent between $\$ 350,000$ and $\$ 400,000$ per year on lobbyists in the state capital. Between 1998 and 2004, the industry spent almost $\$ 9$ million on lobbyists in Washington, DC (Klein, 2005:59).

4.7 Political lobbying is important considering that under current legislation a cruise ship may legally discharge raw sewage when it is three miles from shore, grey water virtually anywhere, oily bilge as long as it is filtered to 15 parts per million, and ground solid waste (including food) when a ship is four miles from shore. There are no regulations applying to discharge of incinerator ash (which may contain hazardous waste) into the oceans, few regulations (other than Alaska and California) applying to air emissions, and other than California limited regulation of ballast water.

\section{Discussion}

5.1 Traditional discussions in the sociology of power do not adequately explain the dynamics involving the cruise industry and environmental activists. For that reason, this discussion does not adopt a single perspective from the sociology of power. Instead it draws on the concept of social capital which is not normally used to understand this sort of situation. Introduced by Loury $(1977 ; 1987)$ and developed by Coleman in Foundations of Social Theory, social capital is a useful heuristic device for understanding environmental activism and the cruise industry. Social capital can be intentionally created and increased through social and political activity, and can be the foundation for influencing social policy and the political arena. As will be seen, the cruise industry has been more adept at creating and using social capital than its environmentalist adversaries. Its actions are not so much rooted in conventional forms of social power, but instead reflect skill in persuasion; in conveying implicit awareness to politicians, organizations, and government agencies of costs associated with not supporting the industry's position and agenda; and shaping opinions through subtle influence over the media and other sources of public knowledge and awareness. The following discussion attempts to illustrate the dynamics put into play by the cruise industry in its confrontation by environmental activists. It seeks to explain why some strategies are effective and others are not.

\section{The environmental movement}

5.2 Environmental groups have been most effective when using the judicial system. Bluewater Network successfully used the courts to force the EPA to fulfil its legislated obligations, and to force enforcement of state laws in California. The same strategy was pursued in Washington State by Ocean Advocates (a largely local organization) to ensure enforcement of laws covering a 16,000 gallon discharge of raw sewage by the Norwegian Sun, and by Last Stand in Key West, Florida to force the City of Key West to undertake a quality of life study assessing the impact on the city of growing cruise tourism. The quality of life study in Key West was released in June 2005 (see Murray, 2005) and had a profound impact on the future of cruise tourism in the city; the report supported many of the views previously expressed by industry critics. Success in using the judicial system is grounded in the fact that courts generally make decisions on objective fact rather than on a partisan's ability to shape perception through campaigns or media spending.

5.3 Media campaigns have been used by some in the environmental movement, but with limited impact. Oceana, for example, relied heavily on public relations firms to get its issues into the public domain. While they had limited success around specific actions - a rally with a plane flying overhead trailing a banner 
reading 'Got Sewage? Royal Caribbean Dumps Daily' and their confrontation with Google over dropping of its ads both received national media attention - they fell short of the full potential for impact. One reason is use of multiple public relations firms whose work frequently was not coordinated. There was duplication and in some cases they worked at cross purposes. ${ }^{[1]}$ In addition, media strategies created by public relations firms are fundamentally different than those planned by social activists and involving the grassroots. Largescale grassroots activity was not a part of the campaign and was not created or supported by the largely media-based campaign. Grassroots activity was generally small-scale.

5.4 Oceana's use of the media starkly contrasts with Livable Old Town in Key West. The latter's campaign, run by grassroots community activists, used paid advertising in the local newspaper to get across their view of the issues and often included levity to effectively present their case. The result was a well-informed community and a city government that was continually on the defensive for uncritically embracing cruise tourism. This yielded greater public support and involvement in local social action. For example, in March 2004 the organization called for an hour protest on a day when five cruise ships were in town - more than 10,000 passengers and crew in a town of 27,000 permanent residents. The protest asked local residents to get in their car and drive around the downtown area between $11 \mathrm{AM}$ and noon in order to demonstrate the problem of congestion and crowding caused by cruise tourism. The protest was a resounding success, receiving local, national, and international media attention. The beauty of the action is that even if people failed to turn out, the normal congestion with that number of cruise ships in town would itself have made the point of overcrowding. One leader of grassroots activity was subsequently elected to the City Council in 2005.

5.5 Bluewater Network has used social action events to a limited extent - mainly in relation to concerns about abatement of cruise ship air emissions while docked at a new cruise terminal being planned for San Francisco. Bluewater explains its limited use of these events quite simply: it is better to not have an event than to have an event where few show up.

5.6 Contrast this with the social action Oceana used to launch its campaign against Royal Caribbean. They placed creative and effective full page advertisements in the Miami Herald and Fort Lauderdale's Sun Sentinel on the opening day of the Seatrade Cruise Shipping Convention (the industry's largest annual trade show and conference) in Miami Beach in March 2003. The mood in the Convention's 'Press Room' that morning demonstrated concern among industry executives that Oceana would be a formidable force with which to deal. The ads were used in concert with a press conference and rally planned for midday outside the Convention Centre. Fifteen minutes after the event began senior executives of the cruise industry crossed the street from the Convention Centre to assess Oceana's threat. What they found was a rally with more representatives of the media than demonstrators and more Oceana employees than demonstrators. The aftermath in the 'Press Room' was one of relief. Oceana's strong appearance in advertisements was undercut and its actual threat was no longer taken seriously. Their credibility as a viable threat was lost and could not be undone. Subsequent rallies in other locales were plagued with similarly low turnouts by demonstrators.

5.7 Generally absent in the activism by national organizations is the production of 'blue ribbon' studies used to support or bolster claims and campaigns. There are several exceptions. As already mentioned, The Ocean Conservancy published Cruise Control, a report that presented effectively information about the environmental impact of cruise tourism. Unfortunately, because the organization was receiving money from Royal Caribbean's Ocean Fund, the report's release was inordinately delayed by internal political processes and its contents had lost some of their timeliness. The report was still effective, however it quickly disappeared from the organization's web site, reappeared in a location that was difficult to locate, disappeared again, and reappeared again with TOC's push for the Clean Cruise Ship Act of 2004. Another report, Blowing the Whistle and the Case for Cruise Ship Certification, was issued in 2002 by OBF, but as already mentioned it caused the organization to lose its funding and pass out of existence.

5.8 Bluewater Network has effectively used fact sheets and reports in its lobbying efforts and its public education. The documents have educated legislators and influenced legislative decisions. They have not been limited to Bluewater Network's cruise ship campaign, and have demonstrated the potential of integrating solid research (some with an academic base) in political and social action.

5.9 Two reports issued by the Canadian Centre for Policy Alternatives further illustrate the value of formal studies - these studies, by their nature and sponsorship possessed a degree of social capital. Prior to release in March 2002 of the first report, Cruising - Out of Control (Klein, 2003a), the Canadian Government planned to issue voluntary guidelines for cruise ships operating in Canadian waters. The guidelines were postponed and taken back to the drawing board. They were again near release in September 2003 when the second report, Charting a Course (Klein 2003b) was issued. This report further delayed the release and resulted in a Private Member's Bill in the House of Commons calling on 
Government to follow some of the recommendations made in the report. Though the guidelines were eventually released, their delay and revision suggests that university-based research can have an impact. Environmental activists appear slower than the cruise industry in realizing this.

5.10 Recognizing and appreciating the importance of social capital is a basic problem among environmental activists and organizations. Its importance is not surprising - one need only recall Richard Emerson's (1962) 'Power Dependence Relations' to be reminded that the cruise industry (like any actor engaged in social relations) is not going to be compelled to do something when there is an absence of dependence or lack of a credible threat. Emerson's classic article also reminds us of the importance of coalition building to build power and overcome dependence. Unfortunately, most of the national organizations are more concerned with their own turf than with winning on issues; they tend to be territorial and shy away from working with others as equals. Oceana in its haste to advance its own agenda undermined efforts by others on the same side of the issue, and missed opportunities for more positive outcomes. The problem is confounded further because Pew Charitable Trusts shifted funding to Oceana from local and grass-roots organizations that previously had limited success. Without funding they could not continue.

5.11 A review of environmental activism targeting the cruise industry in the U.S. suggests local organizations have the greatest effectiveness in impacting decision-making and policies. Efforts by Liveable Old Town and Last Stand in Key West have already been mentioned. Also worth identifying are KAHEA The Hawaiian Environmental Alliance which has been a key force in keeping cruise industry practices and behaviour in the media and in maintaining the awareness of government bureaucrats and elected officials; Friends of Casco Bay in Portland (Maine), which was key in the successful push for legislation to control cruise ship discharges in state waters; and Ocean Advocates in Seattle which has kept in the media cruise industry practices and the industry's cosy relationship with the Port of Seattle. Each of these groups has been successful in local actions, many of which have involved coalitions and cooperation with other locallybased groups.

\section{The cruise industry}

5.12 The cruise industry has proven adept at building social capital. Like many industries, cruise corporations use interlocking boards of directors as one source of social capital (see Whitt, 1982). Through their boards of directors, the two largest cruise corporations (controlling 75 per cent of the industry) have direct connections to major mass media, universities, societies that classify cruise ships (e.g., Lloyd's Register in the UK and RINA in Italy), environmental organizations, and foundations that fund environmental organizations. These connections have effectively been used to silence critics and would appear, in concert with close to a billion dollars in spending for advertising, to influence news media coverage. Though anecdotal, several reporters with major newspapers have spoken privately of stories being killed or altered at high levels in the organization because of fear about loss of advertising revenue.

5.13 The news media is also influenced more directly. Newspaper editorial boards in major cruise locations are frequently visited by cruise industry representative and lobbyists who brag about the industry's extreme environmental sensitivity and responsibility. In addition, there are known occasions where senior industry executives have applied pressure to prevent negative media coverage and to have interviews with industry critics cancelled. ${ }^{[2]}$ While these too are anecdotal, the dearth of negative media coverage about the cruise industry and the absence of coverage of key events critical of the industry appear to support these accounts. At the same time, the cruise industry uses the media to project a positive environmental image. Royal Caribbean's annual 'environmental ship of the year' is a good example. Press releases and media coverage focus on the environmental award; they rarely if ever make clear that the award is being given by a company to its own ships and a company repeatedly caught polluting the oceans.

5.14 Another key source of social capital for the cruise industry is political lobbying and campaign contributions. These are tactfully directed to key members of Congressional committees charged with oversight of the industry and members of Congress from states heavily dependent on the cruise industry. For example, among the top recipients of cruise industry money in the US Senate between 1997 and 2004 are the majority leader, the majority whip, eight members of the Appropriations committee (including its chair) and ten members of the Commerce, Science and Transportation Committee. A similar pattern is seen in contributions to members of the US House of Representatives: the industry's large contributions are concentrated on members of three committees: Transportation and Infrastructure, Ways and Means, and Energy and Commerce. The Transportation and Infrastructure Committee includes the Coast Guard and Marine Transportation subcommittee which was assigned the Clean Cruise Ship Act of 2004 and like the Commerce, Science and Transportation Committee in the Senate is generally referred all cruise industry related legislation. The committee's chair, Don Young from Alaska, is the largest recipient of contributions from cruise industry sources (see Klein, 2005:67-74). 
5.15 The industry also spends large sums of money on state elections. In the past four election cycles $(1998$ - 2004) it has spent $\$ 1.6$ million in Florida, $\$ 600,000$ in Alaska, and $\$ 400,000$ in Washington on candidates and campaigns for state office. This is in addition to significant contributions to campaigns for state representation in the U.S. Congress. Campaign contributions, combined with lobbying, are the most effective way to influence legislators and policy making (Rehbein, 2004, quoted in Klein, 2005:67)

5.16 Another strategy the cruise industry effectively uses is 'buying' a green image through donations and grants. This is achieved through funds such as Royal Caribbean's Ocean Fund, the International Council of Cruise Line's Cruise Industry Charitable Foundation, and through direct contributions from cruise lines. The Ocean Fund is touted by Royal Caribbean as proof of its environmental concerns, however no monies are given to organizations directly concerned with cruise ship discharges and emissions - the few that have these concerns either don't receive funding or have had funding withdrawn or not renewed. The largest recipient of money from The Ocean Fund is the US World Wildlife Fund, whose Board Chair is William K. Reilly. In addition to being a paid consultant to and on the Board of Royal Caribbean, Mr. Reilly serves on the boards of the Packard Foundation, Conoco, Dupont, lonics, Eden Springs, and Evergreen Holdings. He also serves on the Board of Trustees of the American Academy in Rome, the National Geographic Society, and Presidio Trust. The World Wildlife Fund helps Royal Caribbean project a green image; Mr. Reilly's involvement on multiple boards of directors contributes to the company's social capital, influence, and power.

5.17 The Cruise Industry Charitable Foundation (CICF) is a bit more sophisticated in its operations than Royal Caribbean. One example among many is the Florida Ocean Alliance Conference held on Carnival Cruise Line's Fantasy on 6 December, 2001. Cosponsored by Carnival Cruise Lines, Canaveral Port Authority, and the International Council of Cruise Lines (ICCL), the conference included a ceremony at which the State of Florida and the cruise industry signed a Memorandum of Understanding (MOU) in which the industry voluntarily committed to follow state and federal laws in its environmental practices. The conference was also used for a photo opportunity where the CICF presented a $\$ 50,000$ check to the University of Miami's Rosenstiel School of Marine and Atmospheric Science. Interestingly, representatives of Carnival Corporation, Royal Caribbean, and the Rosenstiel School all sit on the board of the Florida Oceans Alliance. Shortly after the MOU was signed, ICCL's Cruise Industry Community Fund gave more than $\$ 550,000$ to the Republican Party of Florida - most of the money to be used for Governor Bush's reelection campaign. In addition, Carnival Cruise Line donated $\$ 1.2$ million to the governor's family literacy initiative and the Cruise Industry Charitable Foundation donated an additional $\$ 150,000$ (Smith, 2002).

5.18 The CICF is an effective tool for growing social capital. Between 1998 and 2003 it took in $\$ 4,173,137$. It spent $\$ 596,862$ (14.3 percent of receipts) on overhead and other operations and gave grants totalling $\$ 3,576,275$. Ten organizations account for $\$ 2.2$ million or 62 percent of all money granted by the CICF with a single recipient, Washington Workshops Foundation, received $\$ 1,088,959-30$ percent of all money granted by CICF. The money funded 'at risk' youth from Houston, Miami, New Orleans, New York City, Duluth, Arizona, Alaska, Washington, and California to attend a seven day program of seminars, workshops, and meetings promoting interaction with senior government executives in order to provide students an opportunity to gain a greater understanding and appreciation of the US federal government and its day-to-day operations. The cruise industry benefits when members of Congress get positive press at home for welcoming a delegation of high school-age youth to Washington - the member of Congress feels good about the industry, as do the youth and their families - and the media broadcasts the positive impression further.

5.19 Other groups are not as fortunate as the Washington Workshops Foundation. Thirty-four recipients received $\$ 5000$ or less; their grants collectively totalled $\$ 153,525-4.3$ percent of the total given in grants. The bottom 66 recipients (from a list of 95) collectively received the same amount as spent on overhead and other activities. Many of these are community-based projects directed to people from ethic or racial minority groups. As such, the donations provide huge media visibility at a very low cost.

5.20 The ICCL, as mentioned earlier, entered a partnership with Conservation International in order to reinforce its 'green' image. Conservation International, supported mainly through corporate contributions from companies such as ExxonMobil, British Petroleum, Ford Motor Company, and Starbucks Coffee, has as its Board's Vice Chair Nicholas Pritzker whose family's holdings include controlling interest of Royal Caribbean. Conservation International's name suggests a warm, fuzzy environmental group; not unlike groups like Citizens for the Environment, Evergreen Foundation, the Environmental Conservation Organization, or the National Wetlands Coalition. As pointed out in Las Vegas Mercury (2002), '...those aren't green groups. They're lobbying organizations that represent developers, utilities and mining companies that generally want to, ahem, 'free up' public lands.'

5.21 The ICCL-Conservation International partnership started in 2004 and poses formidable opposition to claims by environmental organizations and advocates for environmental protection. As stated by Jane 
Feldman of the Las Vegas Sierra Club: 'These big groups have resources that us little people in the street-who are really concerned about the environment--don't have ... So they can market this stuff as being environmentally friendly when it's really not' (Las Vegas Mercury, 2002). Manchester Guardian columnist George Monbiot puts it a bit differently when he states, 'Environmentalism, like almost everything else, is in danger of being swallowed by the corporate leviathan. If this happens, it will disappear without a trace. No one threatens its survival as much as the greens who have taken the company shilling' (Monbiot, 2002).

\section{Conclusions}

6.1 It appears that the cruise industry, no matter what its environmental practices, has the money needed to buy an image, to buy positive media visibility (and limit negative media attention), and to influence politicians and government decision-making. The cruise industry is sophisticated in its strategies and has effectively shaped the debate, defined the issues, and placed environmental groups in positions where they appear inept or impotent. Thus far, use of the judicial system has been the only arena in which environmental interests have had a fair and relatively unbiased hearing. But legal cases take money, and the cruise industry with its billions in profits has much deeper pockets.

6.2 The environmental movement, in contrast, has shown much less sophistication. Except for local groups which have had a degree of success on the local level, most of the national organizations lack an appreciation for the depth of the cruise industry's political, business, and social connections and the social capital accrued. They are often naïve about the political force being confronted. The current effort to introduce and enact the Clean Cruise Ship Act of 2004 is an excellent example. While many person hours were devoted to collaboration between environmental organizations, and between these organizations and the sponsors in the U.S. Congress, relatively little attention was given to amassing the social capital needed to push the legislation. Even more salient is that many of these organizations lack an in depth understanding of the way the cruise industry and its partners operate. They are unaware of which members of Congress have been liberally supported and the nature of the support. They also lack cognizance of the tentacles of the cruise industry and its full range of influence. Without this appreciation, environmental groups risk being co-opted, or only succeed in efforts on which the cruise industry wants them to succeed.

6.3 There are lessons to be learned from this study of environmental activism toward the cruise industry in North America. There are several factors that appear important for increasing likelihood of success for environmental activists. Building coalitions is high on the list - activists need to work cooperatively rather than engaging in turf wars or worrying about who is going to get credit. In addition, it is necessary to acknowledge the importance of the media and to see ways to carefully orchestrate media coverage and media campaigns. A clear media strategy can be a key element in any effective campaign.

6.4 There are other insights provided by this analysis. Environmental activists need to be cautious around risks of cooptation. Money given as donations or as grants may be used to influence positions and public efforts; there is always the risk of infiltration of Boards of Directors; and environmental activists need to be on guard for threats posed for green-sounding organizations whose main purpose is to 'greenwash' behaviour that is anything but green.

6.5 Environmental activists especially need to increase their own social capital if they are to effectively confront the cruise industry. Building a strong grassroots base is of key importance. As well, environmental activists need to take a page out of the cruise industry's book of strategies. Use the media, play to and lobby politicians and political parties, and conduct and publish scientific studies or position papers supporting what they espouse. Each alone has limited impact, but a multi-pronged strategy using a broad base of coalitions and grassroots activity will increase the chances for success.

\section{Notes}

${ }^{1}$ These insights are based on personal involvement with Oceana, which used one of this author's books in their campaign and involved the author in a lecture and media tour.

${ }^{2}$ This information is based on the author's meetings with newspaper editorial boards on behalf of ENGOs, and on the author's participation in media interviews in major cruise ports/destinations.

\section{References}

ADAMS, Marilyn.(2002) 'U.S. Cracks Down on Cruise Ship Pollution,' USA Today, 8 November, $<$ http://www.usatoday.com>. 
CHOUDRY, Aziz. (2003) 'Tarzan, Indiana Jones and Conservation International's Global Greenwash Machine,' Z Magazine, 10 October, <http://www.zmag.org/sustainers/content/2003-10/10choudry.cfm>.

COCKERHAM, Sean. (2004) 'Voters to Settle Ship Tax,' Anchorage Daily News, 18 December, < http://www.adn.com/front/v-printer/story/5924969p-5832072c.html>.

DUPONT, Dale K. (2003) 'Pollution Case Haunts Carnival,' Miami Herald, 24 July, <www.miamiherald.com>.

EMERSON, Richard J. (1962) 'Power Dependence Relations,' American Sociological Review, Vol. 27, No. 1, pp. 31-41.

FLETCHER, Ed. (2003) 'Cruise Ships Are in the Cross Hairs,' The Sacramento Bee, 23 June.

GLASS, Joel. (1993) '\$250,000 Award for Reporting At-Sea Plastics Dumping,' Lloyd's List, 12 July, pg. 1.

HERZ, Michael and DAVIS, Joseph. (2002) Cruise Control: A Report On How Cruise Ships Affect the Marine Environment, Washington, DC: The Ocean Conservancy.

JUNEAU EMPIRE (1998) 'Crewman Rewarded for Reporting Pollution,' Juneau Empire, 9 October, $<$ http://www.juneauempire.com>.

KLEIN, Ross A. (2005) Cruise Ship Squeeze: The New Pirates of the Seven Seas , Gabriola Island, British Columbia: New Society Publishers.

KLEIN, Ross A. (2003a) Charting a Course: The Cruise Industry, The Government of Canada, and Purposeful Development, Ottawa: Canadian Centre for Policy Alternatives,

$<$ http://www.cruisejunkie.com/ccpa2.pdf>.

KLEIN, Ross A. (2003b) Cruising -- Out of Control: The Cruise Industry, The Environment, Workers, and the Maritimes, Ottawa: Canadian Centre for Policy Alternatives, <http://www.cruisejunkie.com/cruising.pdf>.

KLEIN, Ross A. (2002) Cruise Ship Blues: The Underside of the Cruise Industry, Gabriola Island, British Columbia: New Society Publishers.

LAIDMAN, Dan. (2003) 'Crystal ships banned from Monterey for 15 years,' Monterey Herald, 18 March, $<$ http://www.montereyherald.com>.

LANGE, Larry. (2004) 'Bill on Cruise Waste Dies,' Seattle Post-Intelligencer, 26 February, <http://seattlepi.nwsource.com/local/162146_cruise26.html>.

LAS VEGAS MERCURY. (2003) 'Quick and Dirty: A Notebook of News and Politics,' Las Vegas Mercury, 30 October, <http://www.lasvegasmercury.com/2003/MERC-Oct-30-Thu-2003/22428503.html>.

LONDNER, Robin. (2003) 'Oceana, Royal Caribbean Argue Over Sewage,' The South Florida Business Journal, 21 July, <http://southflorida.bizjournals.com/southflorida/stories/2003/07/21/daily8.html>.

LOURY, G. (1977) 'A Dynamic Theory of Racial Income Difference,' in P.A. Wallace and A. Le Mund (editors) Women, Minorities, and Employment, Lexington, Mass: Lexington Books.

LOURY, G. (1987) 'Why Should We Care About Group Inequality?' Social Philosophy and Policy, Vol. 5, pp. 249-271.

MADIGAN, Nick. (2003) 'Monterey Bans a Cruise Ship Over Dumping' New York Times, 6 March. $<$ http://www.nytimes.com>.

MCDOWELL, Edwin. (2002) 'For Cruise Ships, A History of Pollution,' New York Times, 16 June, $<$ http://www.nytimes.com>.

MONBIOT, George. (2002) 'Greens Getting Eaten,' The Guardian, 15 January, <http://www.monbiot.com>.

MURRAY, Thomas J. (2005) The Impacts of the Cruise Ship Industry on the Quality of Life in Key West , RFQ No: 04-001 - City of Key West Naval Properties Local Redevelopment Authority.

O'HARA, Timothy. (2004) 'Cruise Money Goes to Marine Sanctuary Visitor Centre,' Key West Citizen, 29 January, <http://keysnews.com>.

OCEANS BLUE FOUNDATION. (2002) Blowing the Whistle and the Case for Cruise Ship Certification, Vancouver: Oceans Blue Foundation. 
<http://oceansblue.org/bluetourism/chartacourse/cruiseship/cruisereport.html>.

PEREZ, Evan. (2003) 'Carnival Fires Pollution Auditors Over False Compliance Reports,' Wall Street Journal, 28 August, pg. D1.

RUIZ-MARRERO, Carmello. (2003) 'The Troubled Marriage of Environmentalists and Oil Companies,' CorpWatch, 22 December, <http://www.corpwatch.org/issues/PID.jsp?articleid=9448>.

SMITH, Adam C. (2002) 'Cruise Group Rewards GOP,' St. Petersburg Times, 23 July, <http://www.sptimes.com/2002/07/23/State/Cruise_group_rewards_.shtml>.

SWEETING, James E.N. and WAYNE, Scott L. (2003) A Shifting Tide: Environmental Challenges and Cruise Industry Response. Washington, DC: Conservation International.

TJADEN, Tracy (2002) 'Cruise Lines Blasted: Tourism-industry Funded Oceans Blue in Hot Water Following Critical Report on Industry,' Business in Vancouver, 12-28 November.

WEISS, Ken. (2003) 'Cruise Line Pollution Prompts Legislation,' Los Angeles Times, 18 August, $<$ http://www.latimes.com>.

WHITT, J. Allen. (1982) Urban Elites and Mass Transportation: The Dialectics of Power. Princeton, New Jersey: Princeton University Press.

YAMANOUCHI, Kelly. (2003) 'Cruise lines admit pollution violations,' Honolulu Advertiser, 12 December 12. <http://the.honoluluadvertiser.com/article/2003/Dec/12/bz/bz02a.html>. 